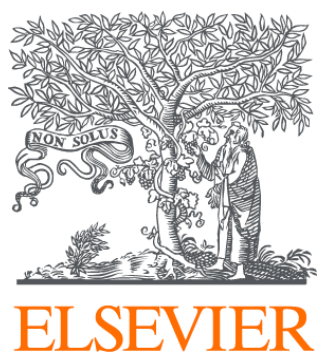

Since January 2020 Elsevier has created a COVID-19 resource centre with free information in English and Mandarin on the novel coronavirus COVID-

19. The COVID-19 resource centre is hosted on Elsevier Connect, the company's public news and information website.

Elsevier hereby grants permission to make all its COVID-19-related research that is available on the COVID-19 resource centre - including this research content - immediately available in PubMed Central and other publicly funded repositories, such as the WHO COVID database with rights for unrestricted research re-use and analyses in any form or by any means with acknowledgement of the original source. These permissions are granted for free by Elsevier for as long as the COVID-19 resource centre remains active. 


\title{
High cytokine levels in perforated acute otitis media exudates containing live bacteria
}

\author{
S. Skovbjerg', K. Roos' ${ }^{2}$ F. Nowrouzian', M. Lindh', S. E. Holm ${ }^{4}$, I. Adlerberth', S. Olofsson ${ }^{3}$ and A. E. Wold' \\ I) Department of Infectious Medicine/Clinical Bacteriology, Institute of Biomedicine, University of Gothenburg, 2) ENT Department, Lundby Hospital, 3) \\ Department of Virology, University of Gothenburg and 4) Institute of Biomedicine, Department of Microbiology and Immunology, University of Gothenburg, \\ Gothenburg, Sweden
}

\section{Abstract}

Acute otitis media (AOM) is an inflammatory response to microbes in the middle ear, sometimes associated with rupture of the tympanic membrane. Human leukocytes produce different patterns of inflammatory mediators in vitro when stimulated with Gram-positive and Gram-negative bacteria, respectively. Here, we investigated the cytokine and prostaglandin $E_{2}\left(P_{G} E_{2}\right)$ responses in middle ear fluids (MEFs) from children with spontaneously perforated AOM, and related the mediator levels to the presence of pathogens detected by culture (live) or PCR (live or dead). Furthermore, the in vivo cytokine pattern was compared with that induced in leukocytes stimulated by dead bacteria in vitro. MEFs with culturable pathogenic bacteria contained more interleukin (IL)-I $\beta$ (median: II0 $\mu \mathrm{g} / \mathrm{L}$ vs. $<7.5 \mu \mathrm{g} / \mathrm{L}$ ), tumour necrosis factor (TNF) $(6.3 \mu \mathrm{g} / \mathrm{L}$ vs. $<2.5 \mu \mathrm{g} / \mathrm{L})$, IL-8 $(410 \mu \mathrm{g} / \mathrm{L}$ vs. $38 \mu \mathrm{g} / \mathrm{L})$ and IL-10 $(0.48 \mu \mathrm{g} / \mathrm{L}$ vs. $<0.30 \mu \mathrm{g} / \mathrm{L})$ than culture-negative fluids, irrespective of PCR findings. IL-6 and PGE 2 were equally abundant $(69-110 \mu \mathrm{g} / \mathrm{L})$ in effusions with live, dead or undetectable bacteria. Cytokine levels were unrelated to bacterial species and to the presence or absence of virus. Similar levels of TNF and IL-6 as found in the MEFs were obtained by in vitro stimulation of leukocytes, whereas II times more IL-I $\beta$ and 3.5 times more IL-8 were produced in vivo, and 22 times more IL-10 was produced in vitro. Vigorous production of proinflammatory cytokines accompanies AOM with membrane rupture, regardless of the causative agent, but the production seems to cease rapidly once the bacteria are killed and fragmented. IL-6 and PGE 2 , however, remain after bacterial disintegration, and may play a role in the resolution phase.

Keywords: Acute otitis media, bacteria, cytokines, middle ear fluid, PCR

Original Submission: 18 March 2009; Revised Submission: 21 September 2009; Accepted: 8 October 2009

Editor: D. Mack

Article published online: 14 October 2009

Clin Microbiol Infect 2010; 16: 1382-1388

I0.1 II I/j. | 469-0691.2010.03083.x

Corresponding author: S. Skovbjerg, Department of Infectious Medicine/Clinical Bacteriology, Institute of Biomedicine, University of Gothenburg, Guldhedsgatan, 10a, SE-4I3 46 Gothenburg, Sweden E-mail: susann.skovbjerg@vgregion.se

\section{Introduction}

Acute otitis media (AOM) is the most common bacterial infection in childhood. Bacteria ascend into the middle ear through the Eustachian tube, commonly after a viral infection. An inflammatory exudate is formed and trapped in the middle ear. In some cases, the tympanic membrane ruptures, by as yet unknown mechanisms.

The major causative agents of AOM are Streptococcus pneumoniae, Haemophilus influenzae and Moraxella catarrhalis; Streptococcus pyogenes is uncommon today [I]. Respiratory viruses are detected in approximately $20 \%$ of AOM middle ear fluids
(MEFs) by culture and/or search for antigens, and even more often by PCR [2]. Their role in pathogenesis is unclear.

A host of inflammatory mediators are produced by tissue macrophages in response to microbes and their products, including prostaglandin $\mathrm{E}_{2}\left(\mathrm{PGE}_{2}\right)$, which causes vasodilatation [3], and tumour necrosis factor (TNF), interleukin (IL)-I $\beta$ and IL-8, which attract and guide neutrophils into the middle ear cavity [4,5]. Some macrophage mediators dampen the inflammatory response. IL-6 downregulates production of TNF and IL-I $\beta$, and appears to be important in the resolution phase [6]. IL-10 counteracts macrophage activation [7], and $\mathrm{PGE}_{2}$ stimulates synthesis of $\mathrm{IL}-\mathrm{IO}$ but suppresses production of TNF [8].

Human leukocytes produce different inflammatory mediators when stimulated with Gram-positive or Gram-negative bacteria in vitro. Intact Gram-positive bacteria induce more TNF than do Gram-negative bacteria, which instead induce more IL-6, IL-8, IL-I0 and PGE 2 [9-II]. Dead and live bacte- 
ria generally induce the same types and amounts of cytokines in human monocytes [10], but fragmented Gram-positive bacteria and isolated cell wall components induce smaller amounts of cytokines [10-12] and may even be inhibitory for cytokine production [13].

In the present study, we investigated the inflammatory mediator response in the middle ear in AOM causing rupture of the tympanic membrane, and related the levels to the presence of live bacteria, bacterial and viral DNA, cytokines and $\mathrm{PGE}_{2}$. The mediator profile in the exudates was compared with that induced by in vitro stimulation of human leukocytes with AOM-causing microbes.

\section{Materials and Methods}

\section{Patients}

We recruited 47 children presenting at an outpatient ear, nose and throat clinic (Lundby Hospital, Gothenburg, Sweden) between January 2004 and May 2005 within $24 \mathrm{~h}$ of spontaneous rupture of the tympanic membrane due to AOM. Patients with chronic otitis media or tympanostomy tubes were excluded. The fluid in the ear canal was sucked up into a container, and the tube was flushed with $0.5 \mathrm{~mL}$ of sterile $\mathrm{NaCl}$ solution, presumed to result in a I: 5 dilution. After culture (see below), the fluid was stored at $-20^{\circ} \mathrm{C}$.

\section{Culture of bacteria from exudate}

Semiquantitative culture of the middle ear exudate was performed by streaking, at the bedside, a calibrated loop (I0 $\mu \mathrm{L})$ on suitable agars, prepared in-house at the Bacteriological Laboratory, Sahlgrenska University Hospital, Gothenburg, Sweden.

The plates were transported within $4 \mathrm{~h}$ to the laboratory, where they were incubated anaerobically (Streptococcus plates) or in air with $5 \% \mathrm{CO}_{2}$ at $37^{\circ} \mathrm{C}$. After $24 \mathrm{~h}$ and $48 \mathrm{~h}$ of culture, AOM pathogens were enumerated and identified using standard methods.

\section{PCR for bacterial pathogens}

S. pneumoniae, $H$. influenzae and Moraxella spp. were detected in MEF by specific PCR. Bacterial DNA was extracted from $100 \mu \mathrm{L}$ of exudate, using the Puregene Yeast \& Gram-positive Bacteria kit (Gentra Systems, Minneapolis, MN, USA) [14]. A duplex PCR assay was used for simultaneous detection of S. pneumoniae and M. catarrhalis, and another PCR assay for detection of $H$. influenzae, as described previously $[15,16]$. The common lower primer was $5^{\prime}$-CTA CGC ATT TCA CCG CTA CAC-3', and the specific upper primers were as follows: for S. pneumoniae, 5'-AAG GTG CAC TTG CAT CAC TAC C-3'; for $H$. influenzae, 5'-CGT ATT
ATC GGA AGA TGA AAG TGC-3'; and for Moraxella spp., 5'-CCC ATA AGC CCT GAC GTT AC-3' [15]. The PCRs were considered to be specific for $S$. pneumoniae and $H$. influenzae, whereas moraxellae other than M. catarrhalis could give positive results (data not shown).

\section{PCR for viral pathogens}

Rhinovirus, coronavirus, influenza A virus, influenza B virus, respiratory syncytial virus, adenovirus, metapneumovirus and enterovirus were detected by PCR as previously described [17]. Nucleic acid from $200 \mu \mathrm{L}$ of diluted specimen was extracted (Magnapure LC robot; (Roche Molecular Systems, Mannheim, Germany), using the Total Nucleic Acid protocol) and amplified (ABI 7500 genetic analyzer; Applied Biosystems, Foster City, CA, USA) using published primers and conditions [17].

\section{In vitro stimulation of blood mononuclear cells}

MEF isolates of S. pneumoniae $(n=3), H$. influenzae $(n=3)$ and M. catarrhalis $(n=1)$ were cultured overnight, harvested in phosphate-buffered saline, washed, suspended at $10 \% / \mathrm{mL}$ (optical density at $580 \mathrm{~nm}$ of I.19), inactivated by exposure to UV light for 18 min (confirmed by a negative viable count) and stored at $-80^{\circ} \mathrm{C}$.

Peripheral blood mononuclear cells were prepared from blood donor buffy coats (Blood Bank, Sahlgrenska University Hospital) by density gradient centrifugation (Lymphoprep; Axis-Shield, Oslo, Norway) for $20 \mathrm{~min}$ at $820 \mathrm{~g}$, washed in endotoxin-free RPMI-1640 with 2 mM L-glutamine (PAA Laboratories $\mathrm{GmbH}$, Linz, Austria), and suspended in triplicate at $2 \times 10^{6} / \mathrm{mL}$ in RPMI- 1640 with $5 \%$ inactivated fetal bovine serum (Invitrogen, San Diego, CA, USA) and $50 \mathrm{mg} / \mathrm{L}$ gentamicin (Sigma-Aldrich, St Louis, MO, USA) in 96-well flat-bottomed plates (Nunc, Roskilde, Denmark). Bacteria were added to achieve final concentrations of $5 \times 10^{5} / \mathrm{mL}$, $5 \times 10^{6} / \mathrm{mL}$ or $5 \times 10^{7} / \mathrm{mL}$. After $24 \mathrm{~h}$ of incubation in a $37^{\circ} \mathrm{C}$ humidified atmosphere with $5 \% \mathrm{CO}_{2}$, supernatants were harvested and stored at $-20^{\circ} \mathrm{C}$ until being analysed.

\section{Quantification of inflammatory mediators}

TNF, IL-I $\beta$, IL-6, IL-8 and IL-I 0 were quantified by ELISA as previously described [18], using monoclonal antibodies and recombinant cytokines from BD Pharmingen (San Diego, CA, USA) or R\&D Systems (Minneapolis, MN, USA) (anti-IL-I $\beta$ antibodies). $\mathrm{PGE}_{2}$ was measured using the Biotrak Enzyme Immunoassay System (Amersham Biosciences UK Limited, Little Chalfont, UK).

\section{Statistics}

Differences between groups were tested for significance with the Mann-Whitney test. Spearman rank correlation was used 
to evaluate relationships between bacterial numbers and cytokine levels.

\section{Results}

\section{Bacterial pathogens detected by culture and PCR}

Forty-seven patients (median age, 26 months; range, 4 months to 14 years) with ruptured tympanic membranes were included. Cultures were positive for a bacterial pathogen in 22 cases (47\%), mainly S. pneumoniae and $H$. influenzae (Table I). Among the 25 pathogen-negative samples, 19 yielded skin commensals such as coagulase-negative staphylococci, Staphylococcus aureus, or diptheroid rods, considered to be contaminants from the external ear canal.

All culture-positive samples were also positive by PCR, except for one sample yielding $S$. pneumoniae in culture but not by PCR (Table I). Another sample yielded S. pyogenes in culture, but the PCR was not designed to detect this pathogen. In seven culture-positive samples, the PCR revealed not only the bacteria found by culture in each sample, but also an additional one or two bacterial pathogens.

Among the 25 culture-negative samples, 21 were also negative by PCR. Thus, only a few additional pathogens were detected with PCR in the samples negative by culture. Dilution ( $I: 5$ and $I: 25)$ to minimize the effect of possible inhibitors did not increase the detection rate, and admixed pneumococcal DNA was readily detected by PCR, ruling out the possibility that negative results were caused by the presence of inhibitory substances in the MEFs.

\section{Presence of viral pathogens}

Twenty-five MEFs were analysed by PCR for the presence of rhinovirus, coronavirus, influenza $A$ virus, influenza $B$ virus, respiratory syncytial virus, adenovirus, metapneumovirus and enterovirus. Five samples (20\%) yielded viruses: rhinovirus $(n=4)$ and coronavirus $(n=1)$. These were all culture-positive for bacterial pathogens: $H$. influenzae $(n=4)$ and/or S. pneumoniae $(n=2)$.

\section{Cytokine levels in relation to microbiological findings} Cytokines and $\mathrm{PGE}_{2}$ were measured in the MEFs and related to culture and PCR findings. The results are shown in Fig. I.

MEFs from which bacterial pathogens were cultured contained high levels of IL-I $\beta$, IL-8, TNF and IL-I0, whereas culture-negative, but PCR-positive, samples had similar levels of these cytokines as MEFs that were negative by both methods. Thus, culture-positive fluids contained II times more IL-I $\beta$ (median II $\mu \mathrm{g} / \mathrm{L}$ vs. $<7.5 \mu \mathrm{g} / \mathrm{L}, \mathrm{P}<0.000 \mathrm{I}$ ), 5.5 times more IL-8 $(410 \mu \mathrm{g} / \mathrm{L}$ vs. $38 \mu \mathrm{g} / \mathrm{L}, \mathrm{P}<0.000 \mathrm{I})$, at least 2.5 times more TNF $(6.3 \mu \mathrm{g} / \mathrm{L}$ vs. $<2.5 \mu \mathrm{g} / \mathrm{L}, \mathrm{P}<0.000 \mathrm{I})$ and at least 1.5 times more IL-10 $(0.48 \mu \mathrm{g} / \mathrm{L}$ vs. $<0.30 \mu \mathrm{g} / \mathrm{L}$, P $0.000 \mathrm{I}$ ) than culture-negative specimens. In contrast, IL-6 and $\mathrm{PGE}_{2}$ were found at equally high levels in both culturepositive and culture-negative samples ( $110 \mu \mathrm{g} / \mathrm{L}$ vs. $100 \mu \mathrm{g} / \mathrm{L}$, and $83 \mu \mathrm{g} / \mathrm{L}$ vs. $69 \mu \mathrm{g} / \mathrm{L}$, respectively). Samples in which viruses were detected did not contain higher cytokine levels than virus-negative samples (data not shown).

Positive MEF samples contained 100-100 000 bacteria/mL. Among culture-positive samples, there was no correlation between population numbers and cytokine levels (data not shown).

\section{Inflammatory mediators in relation to bacterial pathogens}

We compared inflammatory mediators in effusions that contained the Gram-positive S. pneumoniae or the Gram-negative $H$. influenzae, as detected by culture or PCR. No significant difference was seen for any of the investigated mediators (Table 2 and data not shown).

\begin{tabular}{|c|c|c|c|c|c|c|}
\hline & \multirow[b]{2}{*}{$n$} & \multicolumn{4}{|c|}{ A single pathogen } & \multirow[b]{2}{*}{$\begin{array}{l}\text { More than } \\
\text { pathogen }\end{array}$} \\
\hline & & $\begin{array}{l}\text { Streptococcus } \\
\text { pneumoniae }\end{array}$ & $\begin{array}{l}\text { Haemophilus } \\
\text { influenzae }\end{array}$ & $\begin{array}{l}\text { Moraxella } \\
\text { catarrhalis }\end{array}$ & $\begin{array}{l}\text { Streptococcus } \\
\text { pyogenes }\end{array}$ & \\
\hline Assayed MEF & 47 & & & & & \\
\hline Culture-positive & 22 & 10 & 9 & 1 & 1 & $\mathrm{I}^{\mathrm{a}}$ \\
\hline PCR-positive & 20 & 6 & 6 & 0 & $-{ }^{b}$ & $8^{c}$ \\
\hline PCR-negative & 2 & 1 & 0 & 0 & $1^{\mathrm{b}}$ & 0 \\
\hline Culture-negative & 25 & & & & & \\
\hline PCR-positive & 4 & 0 & 0 & 2 & - & $2^{d}$ \\
\hline PCR-negative & 21 & & & & & \\
\hline \multicolumn{7}{|c|}{$\begin{array}{l}\text { as. pneumoniae }+H \text {. influenzae. } \\
\text { b. pyogenes was not assessed in the PCR assay. } \\
\text { 'S. pneumoniae }+H \text {. influenzae }(n=1) ; \text {. pneumoniae }+ \text { M. catarrhalis }(n=2) ; H \text {. influenzae }+ \text { M. catarrhalis }(n=2) \text {; } \\
\text { S. pneumoniae }+H \text {. influenzae }+M \text {. catarrhalis }(n=3) \text {. } \\
\text { dS. pneumoniae }+H \text {. influenzae }(n=1) ; \text {. pneumoniae }+ \text { M. catarrhalis }(n=1) \text {. }\end{array}$} \\
\hline
\end{tabular}

TABLE I. Presence of bacterial pathogens in middle ear fluids (MEFs) from spontaneously ruptured acute otitis media as detected by culture and PCR 

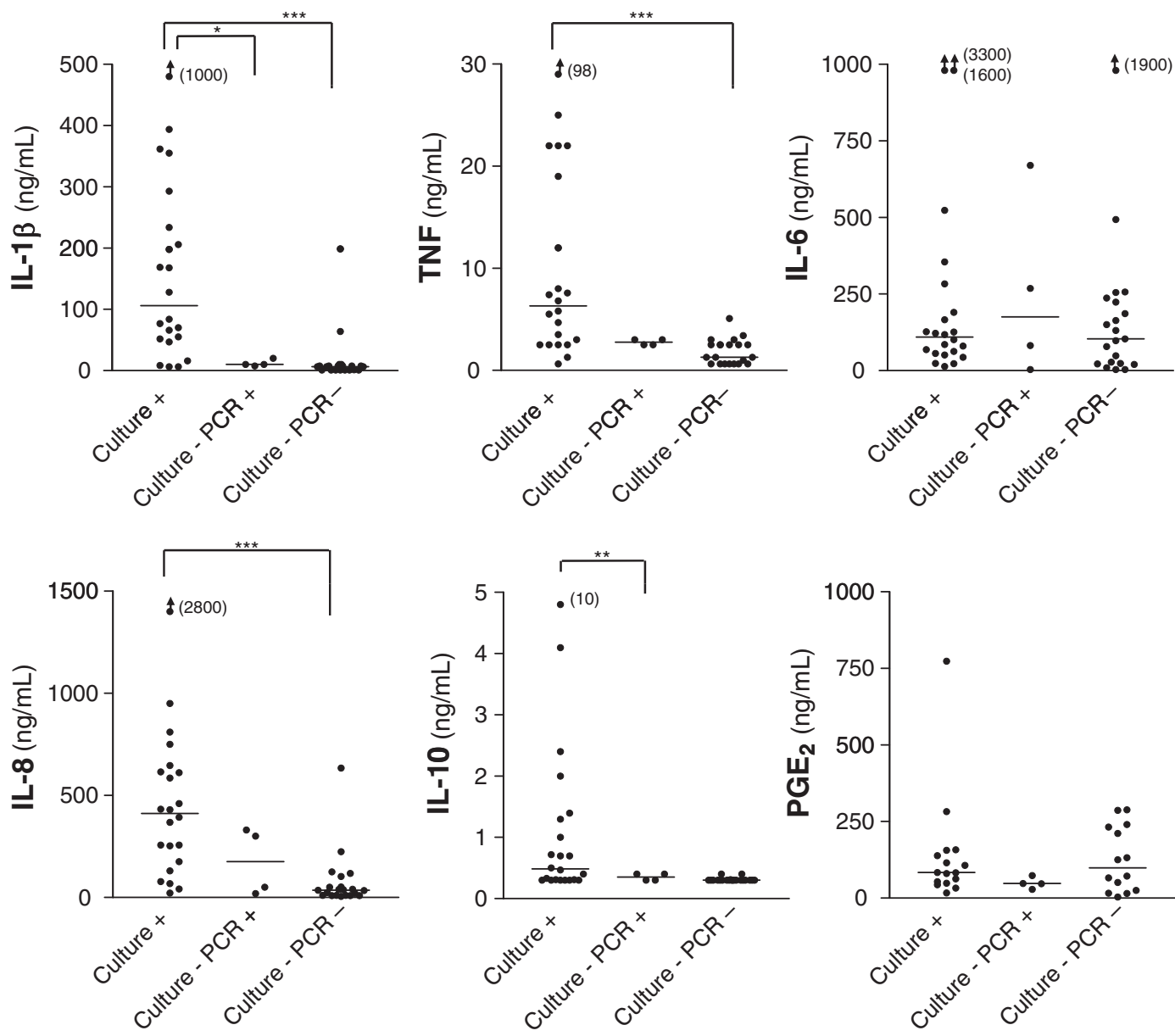

FIG. I. Inflammatory mediators in middle ear effusions with positive bacterial culture, negative culture with positive PCR and negative culture with negative PCR, measured using ELISA. The levels of interleukin (IL)-I $\beta$, tumour necrosis factor (TNF), IL- 8 and IL- 10 were higher in culturepositive middle ear fluids (MEFs) than in culture-negative specimens, irrespective of PCR findings. In contrast, the levels of IL-6 and prostaglan$\operatorname{din} E_{2}\left(P_{G E}\right)$ were equally elevated in effusions with live, dead or undetectable bacteria. ${ }^{*} p<0.05$, ** $p<0.0$ I, ***p $\leq 0.000$ I.

TABLE 2. Inflammatory mediators in middle ear fluids (MEFs) culture-positive for Streptococcus pneumoniae or Haemophilus influenzae

\begin{tabular}{|c|c|c|c|}
\hline & \multicolumn{3}{|c|}{ Inflammatory mediators in MEF (median, range) } \\
\hline & $\begin{array}{l}\text { S. pneumoniae } \\
(n=10)\end{array}$ & $\begin{array}{l}H . \text { influenzae } \\
(n=9)\end{array}$ & p-value \\
\hline IL-I $\beta(\mu \mathrm{g} / \mathrm{L})$ & $110(6.3-390)$ & $170(8.6-1000)$ & 0.97 \\
\hline TNF $(\mu \mathrm{g} / \mathrm{L})$ & $7(<1.3-98)$ & $2.5(<2.5-25)$ & 0.44 \\
\hline IL-6 ( $\mu \mathrm{g} / \mathrm{L})$ & $160(24-1600)$ & $85(14-170)$ & 0.22 \\
\hline IL-8 ( $\mu \mathrm{g} / \mathrm{L})$ & $430(22-810)$ & $590(180-2800)$ & 0.48 \\
\hline IL-10 $(\mu \mathrm{g} / \mathrm{L})$ & $0.48(<0.30-2.0)$ & $0.33(<0.30-4.1)$ & 0.68 \\
\hline $\mathrm{PGE}_{2}(\mu \mathrm{g} / \mathrm{L})$ & $83^{\mathrm{a}}(17-280)$ & $130^{\mathrm{b}}(33-770)$ & 0.78 \\
\hline
\end{tabular}

Inflammatory mediator response after in vitro stimulation of leukocytes with bacterial pathogens

We investigated whether the cytokine pattern seen in MEFs could be replicated by stimulation of human leukocytes with AOM pathogens in vitro. Mononuclear cells from three blood donors were stimulated with three strains each of $S$. pneumoniae and $H$. influenzae and one of $M$. catarrhalis. UV-inactivated bacteria were used at $5 \times 10^{5} / \mathrm{mL}, 5 \times 10^{6} / \mathrm{mL}$ and $5 \times 10^{7} / \mathrm{mL}$, and cytokines were measured in the supernatant after $24 \mathrm{~h}$, previously found to be optimal $[\mathrm{I} 0, \mathrm{I} \mathrm{I}]$. MEF levels of IL-I $\beta$ and IL-8 were, on average, II and 3.5 times higher than could be induced in vitro with an optimal dose of bacteria $\left(5 \times 10^{7} / \mathrm{mL}\right)$ ( $p<0.000 \mathrm{I}$ and $\mathrm{p}$ 0.004, respectively) (Fig. 2). In contrast, IL-I0 levels were 22 times lower in exudates than those obtained 

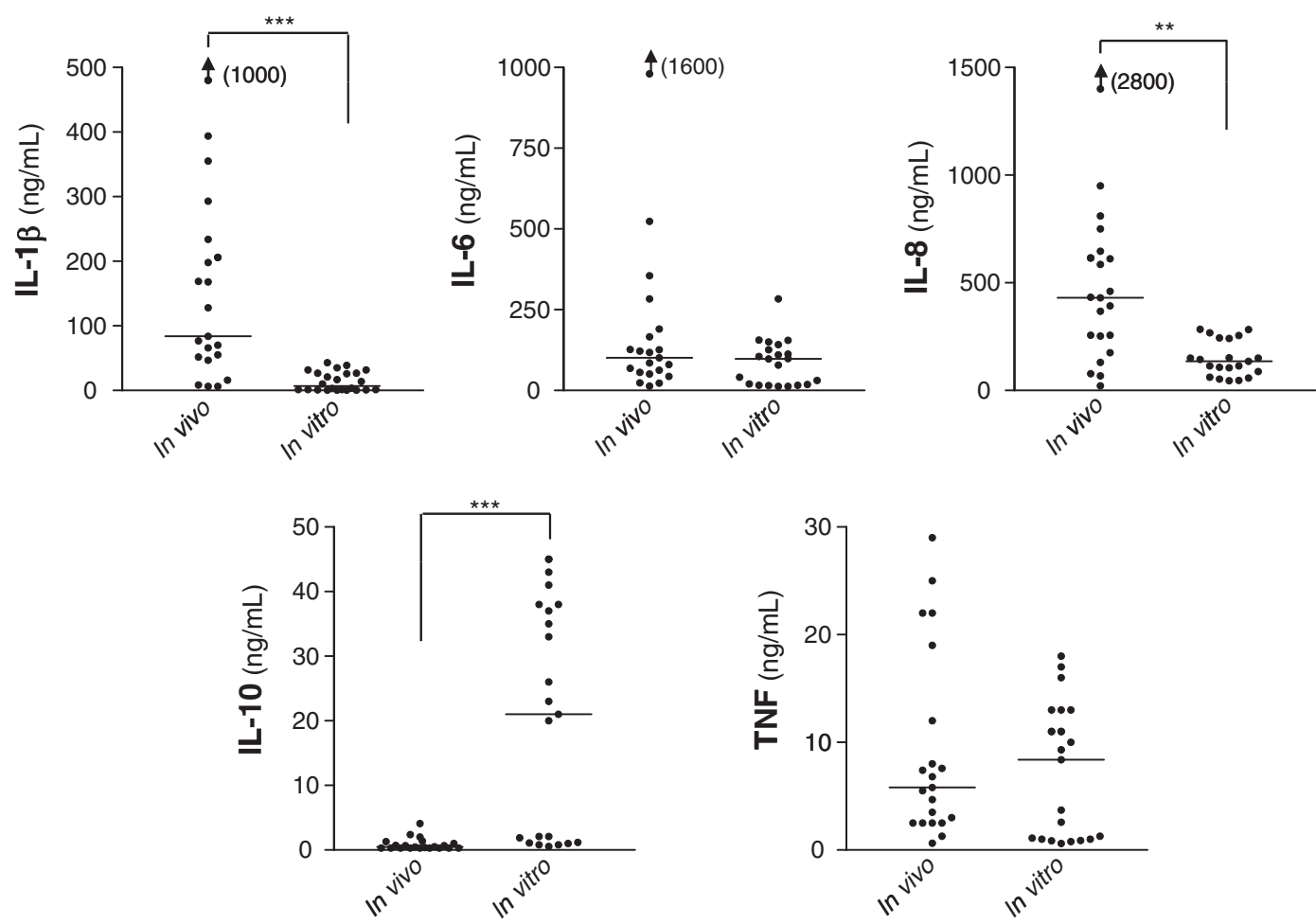

FIG. 2. Mononuclear cells from three blood donors were stimulated with clinical acute otitis media (AOM) isolates of UV-inactivated Streptococcus pneumoniae $(n=3)$, Haemophilus influenzae $(n=3)$ or Moraxella catarrhalis $(n=1)$ at optimal concentrations $\left(5 \times 10^{7}\right.$ bacteria/mL), and the levels of inflammatory mediators were compared with the levels measured in middle ear fluids (MEFs) containing these pathogens. Whereas the levels of interleukin (IL)- 6 and tumour necrosis factor (TNF) in the MEF samples were similar to those in the supernatants from stimulated leukocytes, the AOM exudates contained more IL-I $\beta$ and IL-8, but less IL- I0, than was obtained in vitro. $* *_{\mathrm{p}}<0.00 \mathrm{I}$, ***p $<0.000 \mathrm{I}$.

in vitro ( $\mathrm{P}<0.000 \mathrm{I})$ (Fig. 2), mainly owing to high IL-I0 levels induced in vitro by $H$. influenzae and $M$. catarrhalis. IL- 6 and TNF were produced at approximately the same levels in vitro as those found in culture-positive MEFs (Fig. 2).

\section{Discussion}

In this study, middle ear effusions obtained after spontaneous rupture of the tympanic membrane were examined for live and dead bacteria, viruses and inflammatory mediators.

A major finding was that of strikingly higher levels of IL-I $\beta$, TNF, IL-8 and IL-I 0 in culture-positive than in culture-negative MEFs. Accordingly, in MEFs obtained by tympanocentesis, the levels of IL-I $\beta$, TNF and IL- 8 were two to ten times higher in samples containing live bacteria than in sterile samples [19-2I], and in our studies of secretory otitis media, a condition with long-standing fluid in the middle ear, the levels of not only IL-I $\beta$ and IL-8, but also IL-6, were higher in culturepositive than culture-negative MEFs [16]. Interestingly, the presence of dead bacteria, as revealed by positive PCR but negative culture, was not associated with enhanced cytokine levels. Furthermore, only a few samples that were negative by culture were positive by PCR, indicating that killing of the bacteria is followed quite soon by elimination of bacterial DNA.

We have shown that fragments from decayed Gram-positive bacteria are rather inefficient in triggering cytokine production $[10, I I]$ and, in fact, may even potently downregulate the production of IL-12, TNF and interferon- $\gamma$ [13]. Our results in this study confirm these findings, as the highest cytokine levels were only seen in the presence of intact, live bacteria, suggesting that fragmented bacteria are less stimulatory.

Interestingly, the levels of IL-6 and PGE 2 were strongly elevated even in exudates devoid of viable bacteria. We have observed that IL-6 is also produced in response to fragmented bacteria [I2]. IL-6 is a cytokine that inhibits the production of IL-I $\beta$ and TNF, favours the resolution of the neutrophil infiltrate and initiates an acquired immune response [6,22], thus playing a role in initiating the resolution phase of the infection. It is also possible that the production of IL-6 and $\mathrm{PGE}_{2}$ could continue for a longer time after the initial stimulus than that of other cytokines, and/or that these mediators are not eliminated at the same rate as the other cytokines. 
Thus, in a pneumococcal AOM rat model, IL-6 was observed in the middle ear tissue for at least 5 days after initiation of the infection, whereas its production ceased within $24 \mathrm{~h}$ [23], suggesting slow elimination of this cytokine.

When blood mononuclear cells were stimulated with optimal doses of inactivated bacterial pathogens, similar levels of TNF and IL-6 were obtained as those present in the AOM fluids. However, MEFs contained II times more IL-I $\beta$ and three times more IL- 8 than could be obtained in vitro, but, conversely, 22 times less IL-10 than was generated upon in vitro stimulation of leukocytes. Thus, the inflammatory reaction associated with rupture of the tympanic membrane is associated with exceptionally high levels of IL-I $\beta$, but little IL-I0.

Secretion of biologically active IL-I $\beta$ requires two signals: one signal inducing production of the inactive precursor, pro-IL-I $\beta$; and another signal for activation of caspase-I, leading to the cleavage and export of active IL-I $\beta$ [24]. Caspase-I is activated by formation of an inflammasome in response to cell stress [24]. Thus, the high levels of IL-I $\beta$ seen in spontaneously perforated AOM may be the consequence of severe tissue stress and destruction. However, IL-I $\beta$ may also contribute to destruction, as it induces production of metalloproteases, enzymes that digest connective tissue, a component of the tympanic membrane [25].

We could not detect any significant differences in the levels of inflammatory mediators between effusions yielding the Gram-positive S. pneumoniae or the Gram-negative $H$. influenzae, despite in vitro findings of different responses to these bacteria and to Gram-positives and Gram-negatives in general $[10,11,26]$. This shows that viable bacteria interacting with host tissue produce additional inflammatory stimuli to those provided by the bacterial structures themselves. Serum levels of IL- 6 have actually been shown to be higher in AOM caused by Gram-positive pneumococci than in AOM caused by Gram-negative $H$. influenzae [27], although Gram-negatives in vitro elicit more IL-6 than do Gram-positives [II].

Respiratory viruses could be detected in $20 \%$ of the samples that were invariably culture-positive for bacteria. This low rate contrasts with those found in other studies [2], and might be explained by dilution of samples. However, AOM with spontaneous rupture of the tympanic membrane may have a mainly bacterial aetiology. Studies have shown higher levels of IL-8 in virus-containing exudates [28], but we saw no effect of the absence or presence of viruses on any of the inflammatory mediators.

In half of the MEFs, we found no recognized pathogen, either by culture or by PCR. Could novel species, perhaps difficult to culture, be responsible for infection in apparently pathogen-negative otitis media effusions?
The bacterium Alloiococcus otitidis has been detected by PCR in $25 \%$ of MEFs from children with AOM, but the clinical significance is doubtful [29]. However, an infection so powerful as to sever the tympanic membrane is probably caused by highly virulent bacteria such as pneumococci [30]. In conclusion, we assume that the pathogens of importance are S. pneumoniae, $H$. influenzae and, to a lesser extent, M. catarrhalis and S. pyogenes, and that the absence of detectable bacteria depends on their active elimination shortly after killing of the bacteria. Our results further suggest that once the bacteria are dead and fragmented, the production of proinflammatory cytokines ceases rapidly.

\section{Acknowledgements}

We thank C. Welinder-Olsson for expert advice concerning the bacterial PCR.

\section{Transparency Declaration}

The study was supported by Swedish Research Council No. 14017 and the Sahlgrenska Academy, University of Gothenburg. There are no dual or conflicting interests.

\section{References}

I. Kilpi T, Herva E, Kaijalainen T, Syrjanen R, Takala AK. Bacteriology of acute otitis media in a cohort of Finnish children followed for the first two years of life. Pediatr Infect Dis J 200I; 20: 654-662.

2. Heikkinen T, Chonmaitree T. Importance of respiratory viruses in acute otitis media. Clin Microbiol Rev 2003; 16: 230-24I.

3. Davies P, Bailey PJ, Goldenberg MM, Ford-Hutchinson AW. The role of arachidonic acid oxygenation products in pain and inflammation. Annu Rev Immunol 1984; 2: 335-357.

4. Pober JS, Cotran RS. Cytokines and endothelial cell biology. Physiol Rev 1990; 70: 427-451.

5. Mukaida N, Harada A, Matsushima K. Interleukin-8 (IL-8) and monocyte chemotactic and activating factor (MCAF/MCP-I), chemokines essentially involved in inflammatory and immune reactions. Cytokine Growth Factor Rev 1998; 9: 9-23.

6. Kaplanski G, Marin V, Montero-Julian F, Mantovani A, Farnarier C. IL6: a regulator of the transition from neutrophil to monocyte recruitment during inflammation. Trends Immunol 2003; 24: 25-29.

7. Conti $\mathrm{P}, \mathrm{Kempuraj} \mathrm{D}$, Kandere $\mathrm{K}$ et al. IL-10, an inflammatory/inhibitory cytokine, but not always. Immunol Lett 2003; 86: 123-129.

8. Aloisi F, De Simone R, Columba-Cabezas S, Levi G. Opposite effects of interferon-gamma and prostaglandin E2 on tumor necrosis factor and interleukin-10 production in microglia: a regulatory loop controlling microglia pro- and anti-inflammatory activities. J Neurosci Res 1999; 56: 57I-580.

9. Hessle CC, Andersson B, Wold AE. Gram-negative, but not Grampositive, bacteria elicit strong PGE2 production in human monocytes. Inflammation 2003; 27: 329-332. 
10. Hessle C, Andersson B, Wold AE. Gram-positive bacteria are potent inducers of monocytic interleukin-I2 (IL-12) while gram-negative bacteria preferentially stimulate IL-I0 production. Infect Immun 2000; 68: 358I-3586.

II. Hessle CC, Andersson B, Wold AE. Gram-positive and Gram-negative bacteria elicit different patterns of pro-inflammatory cytokines in human monocytes. Cytokine 2005; 30: 3II-3I8.

12. Barkman C, Martner A, Hessle C, Wold AE. Soluble bacterial constituents down-regulate secretion of IL-I2 in response to intact Grampositive bacteria. Microbes Infect 2008; 10: 1484-1493.

13. Martner A, Skovbjerg S, Paton JC, Wold AE. Streptococcus pneumoniae autolysis prevents phagocytosis and production of phagocyte-activating cytokines. Infect Immun 2009; 77: 3826-3837.

14. Fritzell P, Bergstrom T, Welinder-Olsson C. Detection of bacterial DNA in painful degenerated spinal discs in patients without signs of clinical infection. Eur Spine J 2004; 13: 702-706.

I5. Hendolin PH, Markkanen A, Ylikoski J, Wahlfors JJ. Use of multiplex PCR for simultaneous detection of four bacterial species in middle ear effusions. J Clin Microbiol 1997; 35: 2854-2858.

16. Skovbjerg S, Roos K, Holm SE et al. Spray bacteriotherapy decreases middle ear fluid in children with secretory otitis media. Arch Dis Child 2009; 94: 92-98.

17. Brittain-Long R, Nord S, Olofsson S, Westin J, Anderson LM, Lindh M. Multiplex real-time PCR for detection of respiratory tract infections. J Clin Virol 2008; 41: 53-56.

18. Karlsson H, Hessle C, Rudin A. Innate immune responses of human neonatal cells to bacteria from the normal gastrointestinal flora. Infect Immun 2002; 70: 6688-6696.

19. Barzilai A, Leibovitz E, Laver JH et al. Dynamics of interleukin-I production in middle ear fluid during acute otitis media treated with antibiotics. Infection 1999; 27: 173-176.

20. Barzilai A, Dekel B, Dagan R, Passwell JH, Leibovitz E. Cytokine analysis of middle ear effusions during acute otitis media: significant reduction in tumor necrosis factor alpha concentrations correlates with bacterial eradication. Pediatr Infect Dis J 1999; 18: 30I-303.

21. Leibovitz E, Dagan R, Laver JH et al. Interleukin 8 in middle ear fluid during acute otitis media: correlation with aetiology and bacterial eradication. Arch Dis Child 2000; 82: 165-168.

22. Jones SA. Directing transition from innate to acquired immunity: defining a role for IL-6. J Immunol 2005; I75: 3463-3468.

23. Forseni M, Melhus A, Ryan AF, Bagger-Sjoback D, Hultcrantz M. Detection and localization of interleukin- 6 in the rat middle ear during experimental acute otitis media, using mRNA in situ hybridization and immunohistochemistry. Int J Pediatr Otorhinolaryngol 200।; 57: II5-121.

24. Mariathasan S, Monack DM. Inflammasome adaptors and sensors: intracellular regulators of infection and inflammation. Nat Rev Immunol 2007; 7: $31-40$.

25. Havemose-Poulsen A, Holmstrup P. Factors affecting IL-I-mediated collagen metabolism by fibroblasts and the pathogenesis of periodontal disease: a review of the literature. Crit Rev Oral Biol Med 1997; 8: 217-236.

26. Arva E, Andersson B. Induction of phagocyte-stimulating cytokines by in vitro stimulation of human peripheral blood mononuclear cells with Haemophilus influenzae. Scand J Immunol 1999; 49: 4II-4I6.

27. Heikkinen T, Ghaffar F, Okorodudu AO, Chonmaitree T. Serum interleukin- 6 in bacterial and nonbacterial acute otitis media. Pediatrics 1998; 102: 296-299.

28. Chonmaitree T, Patel JA, Sim T et al. Role of leukotriene B4 and interleukin-8 in acute bacterial and viral otitis media. Ann Otol Rhinol Laryngol 1996; 105: 968-974.

29. Leskinen K, Hendolin P, Virolainen-Julkunen A, Ylikoski J, Jero J. Alloiococcus otitidis in acute otitis media. Int J Pediatr Otorhinolaryngol 2004; 68: 5I-56.

30. Palmu AA, Herva E, Savolainen H, Karma P, Makela PH, Kilpi TM. Association of clinical signs and symptoms with bacterial findings in acute otitis media. Clin Infect Dis 2004; 38: 234-242. 